University of North Florida

UNIVERSITY of

NORTH FLORIDA.

UNF Digital Commons

Library Faculty Presentations \& Publications

Thomas G. Carpenter Library

$12-31-2011$

\title{
Cookbooks: Preserving Jewish Tradition
}

Daniel Feinberg

University of North Florida, daniel.feinberg@unf.edu

Alice Crosetto

Follow this and additional works at: https://digitalcommons.unf.edu/library_facpub

Part of the Library and Information Science Commons

\section{Recommended Citation}

Feinberg, Daniel, and Alice Crosetto. 2011. “Cookbooks: Preserving Jewish Tradition”. Judaica Librarianship 16 (1), 149-72. https://doi.org/10.14263/2330-2976.1010.

This Article is brought to you for free and open access by the Thomas G. Carpenter Library at UNF Digital Commons. It has been accepted for inclusion in Library Faculty Presentations \& Publications by an authorized administrator of UNF Digital Commons. For more information, please contact Digital Projects.

(C) 12-31-2011 All Rights Reserved

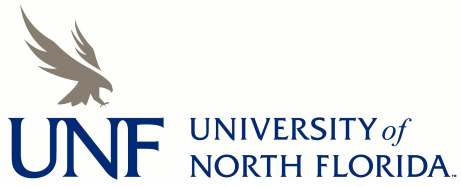




\title{
Cookbooks:
}

\section{Preserving Jewish Tradition}

\author{
Daniel E. Feinberg and Alice Crosetto
}

\begin{abstract}
Culinary traditions have played an integral role in the Jewish religion from its very beginning. Families have continually passed down these traditions from one generation to the next as a means to preserve Jewish culture as well as to maintain their Jewish identity. The authors propose that one of the methods of preserving and transmitting these culinary traditions, traditions clearly rooted in oral tradition, has been through the cookbook. While the written cookbook continues to be popular and marketable, traditional cookbook contents are becoming increasingly available online. In saving recipes for future generations, cookbooks preserve religious, cultural, and traditional elements of Jewish life. As important as it is for Jewish libraries to consider the value of cookbooks in preserving Judaism, non-Jewish libraries, from academic to public, and from K-12 to special, can also share in this mission. Passing cookbooks down through generations not only strengthens culinary cuisine and traditions, but also preserves memories, both familial and religious.
\end{abstract}

For Jews, the saying you are what you eat is a very real statement. "The purpose of eating and drinking is to give courage and strength to better serve God by using this energy to study, pray, and practice the teachings and lessons of the Torah" (Schwartz 2008, p. xiii). The laws of kashrut, as well as fasting and preparing elaborate meals, contribute to being Jewish. The remains of food are forever in the body and the soul. In the words of one food writer, "The proper food keeps both body and soul healthy. The physical becomes the spiritual, as we approach G-d through eating, worshiping at this unique altar, the table" (Cohen 2000, p. 22). In many people's minds, food is sacred as evidenced in examining culinary traditions at Jewish holidays. Judaism is more than a religion; it is a culture, a way of life. As in most religions and cultures, family, holidays, prayer, and tradition are integral elements of Judaism. Throughout history and regardless of denomination or sect, families attend synagogue for Shabbat and then return to their homes for communal meals. Recipes handed down from generation to genera- 
tion are in fact the blueprints for communal meals. As a support and preserver of oral tradition, written recipes became essential. Some consider the Ten Commandments and the tenets outlined in the Torah as the inspiration for the earliest of Jewish recipes. From the Ten Commandments “. . . appeared instructions which have resulted in the development of some of the most typical Jewish foods ..." (Rose 2004, p. xiii). Thus began the laws governing foods that need to be adhered to and passed on according to Jewish precepts.

As families grow, it is often later generations that seek to find and redefine themselves through Judaism, be it religion or culture. These young adults are often those who want to ground their lives in "... their roots and who question elderly relatives to track down cookbooks in seeking out the original recipes" (Nathan 1998, p. 4). As generations ensue, younger children are left with these recipes and cookbooks and guides to their history. "Cuisine is one of the most distinctive expressions of an ethnic group, or, in modern times, a nation. Frequently, the last sign of an individual's attachment to his roots before total assimilation into the host community is the consumption of distinctive kinds of food" (De Silva 2005, p. 112). Memories are more than those of going to the synagogue; they are time spent in the kitchen preparing meals, they are the time spent going through one's family secrets, but even more so, they involve growth and learning tradition. People's eating habits truly express and reflect their culture or religion. In some respect, one can get a "rough stereotyped portrait" of a person simply by looking at what they eat (Kramer 2007, pp. 1-2). Prominent Jewish cook and author Joan Nathan states that assimilated second-generation Americans can use her cookbooks to return to their Jewish roots in order to "understand the old tastes" (Nathan 1998, p. 27). Just as libraries contain the manuscripts and books that preserve societies' culture and thoughts, libraries should provide access to cookbooks that preserve Jewish food and cultural traditions.

Food has always been sacred to Jews because according to Jewish precepts, God has created it as sustenance for humans. "While some foods serve as a sacred purpose because they are rich or rare, others are valued for practical, social, or religious reasons, still others for the way they guide as along the paths of ancestral memory ..." (Luard 2001, p. 54). Furthermore, holidays such as Passover allow symbolic foods to emerge and often take center stage. For example, fruits and eggs stand for renewal and new life, while salt water represents the shedding of tears during the Egyptian exodus. And during Rosh Hashanah, apples and sweet challah are dipped into honey to hope for a sweet and healthy new year (Luard 2001, introd.). Cookbooks have played an important role in preserving some culinary traditions.

In Jewish cooking, maintaining kashrut has been challenging for a variety of reasons, such as the proximity of a kosher butcher or the inability to locate specific food items. The Hebrew root of the word kosher means "ritually fit." Therefore, the law determines if something is "fit for consumption." According to Jewish precepts, the decision to follow these laws is thought to be healthier and, more importantly, has been instrumental in keeping Jews following kashrut for millennia (Greene 1985, p. 6). "Of course, the association of blessings and eating did not commence with the rabbis. The Torah already requires 
that 'you shall eat, and be sated, and bless the Lord, your God, for the earth which He gave you' (Deut 8:10)" (Kramer 2007, p. 73). According to Jewish law, the reality of keeping kosher is to follow the word of God; however, one might realize that this kashrut is upheld due to familial traditions. Also the problem of certain foods being inaccessible to Jews makes following recipes more complex and often harder to prepare. However, these limitations do not prevent Jewish cookbooks from being filled with recipes that are diverse and delectable (Greene 1985, p. 3). Instead, the incorporation of ingredients from around the world took shape and the creation of foods that have been modified from the typical Ashkenazic dishes have become traditional. This represents one of the important elements of Jewish cookbooks: bringing elements of global awareness to the reader.

Cookbooks have also been instrumental throughout history as a way of preserving cooking and culture. The memories of traditional Shabbat dinners, Rosh Hashanah celebrations, and seders, for example, will forever flood Jewish people's minds. Linda Amster states, "Foods shape our memories of home and childhood, and I am not sure I ever approach a Friday night without recalling, at least for a moment, the traditional Sabbath dinner-even though I often complained about it as a child" (Amster 2003, p. xvii).

Food studies, although considered a recent phenomenon by some, has consistently been researched by numerous academic disciplines, including anthropology, psychology, and sociology. In Tasting Food, Tasting Freedom (2006), the anthropologist Sidney W. Mintz states that humans have assigned histories to food that has raised it to a higher status than its biological function-thus further separating the human species from animals-and that the symbolism in food has little to do with the food itself. One of the functions of food symbolism is the ability of food to convey cultural identity. Much has been written regarding the pivotal role that food plays in the rituals, religious obligations, and everyday customs of Jews worldwide. A review of the literature regarding the role and subsequent significance that food has in Judaism reveals numerous insightful texts. For example, John Cooper's Eat and Be Satisfied: $a$ Social History of Jewish Food provides an excellent overview of food and Judaism beginning with Biblical food and dietary laws, through the Talmudic Age and Middle Ages, then concluding with the traditions of the Sephardim and Central and Eastern European Jews. Food \& Judaism (Greenspoon 2005) contains a variety of global Jewish food topics including the following noteworthy articles: Joan Nathan's "A Social History of Jewish Food in America" and Cara De Silva's "In Memory's Kitchen."

If food has the ability to convey cultural identity, then cookbooks, the very texts that contain food formulas-that is, recipes as well as supplemental textdeserve academic study. A limited number of studies and research have been conducted by noteworthy academics who detail the role that cookbooks themselves play in preserving Jewish culture, tradition, and familial bonds. In her indepth analysis of historical cookbooks, "The Kosher Gourmet in the NineteenthCentury Kitchen: Three Jewish Cookbooks in Historical Perspective” (1987a), Barbara Kirshenblatt-Gimblett contends that these cookbooks are manuals for 
the preparation of Anglo-Jewish cuisine and invaluable resources for social historians that mirror society's customs of the time as well as demonstrate the compatibility of Jewish ritual with non-Jewish societal norms of the times. Passing on recipes, entertaining and household instructions, and guidelines for keeping a kosher kitchen are just some of the common elements in these cookbooks. Three years later (1990), in "Kitchen Judaism," Kirshenblatt-Gimblett continues her analysis of Jewish cookbooks as texts that represent Jewish cuisine and social life in nineteenth-century America. "Aunt Babette's" Cookbook was written in 1883 for German Reform Jews who had rejected certain ritual requirements of food. The subsequent publication in 1923 of Fannie Fox's Cook Book revealed obvious differences in Jewish culinary practices since the publication of "Aunt Babette's." Kirshenblatt-Gimblett states that Greenbaum's 1918 Jewish Cook Book demonstrates the need to address the substantial wave of Jewish immigrants in culinary texts as well as the current trend to Americanize Jewish food. She also details two noteworthy additions to cookbook publication: first, Jewish newspapers that issued cookbooks and advertised for the food industry in its transmission of culinary traditions and innovations; and secondly, the onset of charity cookbooks, to date the most prolific genre of Jewish cookbooks, and cookbooks created by synagogue sisterhoods.

Additional research documenting the value of non-American Jewish cookbooks has been conducted. In her 2006 examination of four post-Soviet era Jewish cookbooks, "You Are What They Ate: Russian Jews Reclaim Their Foodways," Alice Nakhimovsky identifies the specific elements in each book that illustrate current Jewish culinary practices. She notes that although challenges still exist in these texts, such as their minimization of the value of kashrut, the lack of recipes traditionally passed down from ancestors, and the maintenance of nonJewish names of recipes of obviously Jewish foods, the current generation of Russian Jews is using these texts to connect to their Jewish ancestry. Carol Bardenstein examines cookbooks-memoirs of Middle Eastern exiles in "The Gender of Nostalgia" (2006). She reveals that food provides a unique operation of memory and collective identity, cookbooks transmit and preserve memoirs especially important for those relocated individuals whose ability to maintain a cultural identity is challenged in the immigration process. Just as Jewish cookbooks are valued as cultural texts within the Jewish community, other cultures also utilize the cookbook as a preservation vehicle. Rosalyn Collings Eves explores the function of recipes and associated text in "A Recipe for Remembrance: Memory and Identity in African-American Women's Cookbooks" (2005). Eves states that these cookbooks provide not only instruction in food preparation but also the means for women to address current cultural stereotypes. In using the term "memory texts," she establishes the importance and the valuable role that cookbooks play in decoding tradition as well as preserving communal identify via food and passing down this knowledge to future generations. While researchers have documented the value of food, the importance of food in Judaism, and the impact of cookbooks in preserving cultural identity, we have discovered no research that explores the role that libraries play in preserving Jewish culture by maintaining a collection of Jewish cookbooks for patron 
usage. Exploration of the reasons why libraries ought to provide access to these culinary texts is required. That research should demonstrate, in turn, that both libraries and communities value the presence and preservation of these resources.

Jewish cookbooks contain the means, that is, cherished recipes, for calming hunger and comforting a troubled soul; they also tie Jews to their roots. "And while we tend to think of cooking as a delight to our senses, the relationships formed through the creation of these culinary compositions are social, cultural, and economic" (Theophano 2002, p. 12). So in order to preserve Jewish culture and best-kept family secrets, women have created these personal manuscripts, these cooking guides per se, of the past and the present. Cookbooks have been created for fundraisers for synagogues and temples; they have given families the joy of serving tradition for generations (Theophano 2002, p. 49). From children's cookbooks to more traditional ones, the message is clear: passing on tradition is expected for all Jews. The fact of the matter, writes Janet Theophano (2002), "Recipe books allude to meals and events, people and places, successes and failures, joys and sorrows, lives and deaths of those loved and known. In summary, they represent the life worlds-past present-of their creators" (p. 82). Libraries serve Jewish populations as well preserve Jewish culture. By maintaining appropriate resources, especially cookbooks, libraries contain knowledge of Judaism and serve Jewish communities around the world. "Cookbooks reveal culinary culture, family and religious values, technology, and domestic economy" (Pollak 2005, p. 133). This represents yet another reason why cookbooks have been and continue to be collected by people and libraries. Cookbooks act as diaries and personalized mirrors of the past.

Recipes alone are malleable. However, these changes and modifications proceed in creating new family favorites. More specifically, tradition must remain unchanged unless one is looking to revise tradition. "Jewish food is no stranger to innovation-how else could it have survived as a recognizable cuisine through so many vicissitudes of fortune?" (Rose 2004, p. xvii). As Jews left their homelands due to different historical circumstances and exile, their lives changed, as did their recipes. For example, Charoseth represents a recipe that has undergone changes due to the diversity in the geographical locations of Jewish families. Charoseth, the Passover dish that Ashkenazi Jews prepare with apples, cinnamon, nuts, and wine, is, for example, prepared with apricots, dates, figs, nuts, and wine by Yemenite Jews (Theophano 2002, p. 50). Families have easily changed Jewish cooking, while preserving some basic recipes, in order to bring forth innovative and new traditions often due to geographical locations and availability of traditional ingredients.

When speaking of cookbooks and recipes, one cannot forget the symbolism of the kitchen. "For Russian Jewish immigrant women, the kitchen is the seat of their power and a safe venue to play out their enthusiasm for innovation while also choosing at times to resist change" (Jochnowitz 2005, p. 17). While in traditional Judaism men are dominant figures in synagogues, women, stereotypically, dominate kitchens. One might speculate that just as the Torah is the inner strength of the synagogue, the cookbook could be the inner strength of 
the Jewish household. As men study the Torah to pass down history, religion, and morals, women compile cookbooks to pass down the "gift of vital practical knowledge." In the past, passing down a cookbook to a daughter signified the change of a young woman into adulthood. There is no doubt, then, that this matriarchal world is passing itself along, through the written word, as a guide to carrying on family food traditions (Theophano 2002, pp. 86-87). One must not forget, though, that this stereotype of the man being the upholder of Jewish religious tradition and the woman being the Jewish homemaker may not be as true today as it was a hundred years ago. However, the premise of the cookbook being crucial is still true; anyone can use it to remember, enhance, and preserve Judaism.

The concept of the cookbook as personal diary and mirror of the past is again worth mentioning. "The themes found in cookbooks are timeless: life and death, youth and age, faithfulness and betrayal, memory and forgetfulness. Yet, cookbooks also tell us how to make beauty and meaning in the midst of the mundane" (Theophano 2002, p. 6). In some respect Jewish cookbooks have acted like guides and outlets for centuries. In the Passover Haggadah, acting as a prayer book and cookbook, individuals are instructed to make certain ceremonial foods for the meal-service. To show the importance of these meals, some families ask guests to come and sign their name and year inside the Haggadot (Pollak 2005, p. 136).

A more in-depth examination of the cookbook reveals that although most see the cookbook as merely a vehicle for the instruction of food preparation, the reader not only learns how to prepare food, but also discovers that the recipes themselves can provide information about a culture, specific geographic regions and historical time periods, seasons, events, even an audience. Just as important as the recipes is the wealth of valuable information contained within the covers. Most of the time, this surplus text is overlooked; however, readers can learn about the history of a culture or a place, or about the sponsoring organization, significant features of a religion, life cycle components; biographies. Most cookbooks contain graphics, not only of the food, but also of individuals, artifacts, maps, and much more.

Today, cookbooks are studied, preserved, and collected, not just by individuals, but by libraries and organizations. Usually cookbooks reveal their purpose. Early cookbooks from the late nineteenth and early twentieth century were instructional. Later on many organizations discovered that cookbooks were a great way to raise funds. And now, cookbooks are how-to-guides for keeping up with popular trends. Jewish cookbooks do all of these things-and even more. Jewish cookbooks were influenced by cookbooks in America throughout the nineteenth century. "The introduction to Smiley's Cookbook and Universal Household Guide, published in 1901, notes: Jewish cookery is becoming much like that of their Christian neighbors, as, except among the more denominationally strict, the old restrictions are melting away" (Nathan 1998, p. 16). During this period assimilation obviously occurred. But it is also apparent that many traditions and recipes were saved unaltered, for otherwise who knows what would happen next? 
The following are examples of Jewish cookbooks that have made contributions to society. Esther Levy's 1871 Jewish Cookery Book on Principles of Economy: Adapted for Jewish Housekeepers with Medicinal Recipes and Other Valuable Information Relative to Housekeeping and Domestic Management, considered the first American Jewish cookbook, covered all aspects of Jewish home life. Levy saw her book as a guide for keeping a Jewish home that was based on what she observed in her Philadelphia German Jewish community. Lizzie Kander's The Settlement Cook Book: The Way to a Man's Heart (1901) and all of its subsequent versions have to date sold over two million copies. Originally published to benefit the first settlement house in Milwaukee, this title helped countless immigrants adapt to a new country while at the same time it preserved a slice of history. Not only were recipes included, but also other helpful tips for the house, such as washing dishes and setting the table. The organizational (sometimes called charity) cookbook, which was originally published by private groups, is now an industry all in itself. It is not an exclusively Jewish genre, but it does represent one of the largest percentages of Jewish cookbook types. Various groups, schools, synagogues, and women's organizations compile their favorite recipes in order to raise funds for a variety of projects. And, as mentioned earlier, the surplus texts in these cookbooks contain a wealth of personal, organizational, and regional information that may not exist anywhere else.

Recipes and cookbooks played an important role in Jewish history even during the Holocaust. During this horrific time, when meager amounts of food rations were given out, Jews were happy to receive even a loaf of bread. The expression "cooking with the mouth" became most popular and meaningful during this time. "Cooking with the mouth," which means to talk through recipes, enabled captives to describe their cooking prior to their imprisonment. These types of explanations were taken very seriously. A survivor even stated that all Jews did it (De Silva 1993, p. xxix). Whether it was a way to get their minds off of the torturous times, or simply a way to remember their previous everyday existence, this type of remembrance made their current situation more bearable. One survivor recalled, "In order to survive you had to have an imagination. Fantasies about food were like a fantasy that you have about how the outside is if you are inside" (De Silva 2005, p. 111). This sense of freedom to remember food brought upon the freedom to remember how families ate, lived, and thrived on Judaism as religion and culture.

While Jews were taken away from their homes, family, and synagogues, they did not give up on saving their religion, preserving their culture, and in this case, cookbooks. Mina Pachter, a Holocaust victim, made sure to find a way to pass on a cookbook that she and other women in the Terezin concentration camp created while imprisoned. Amazingly enough, a survivor sent Mrs. Pachter's book to her daughter, who lived in Palestine. And so the Terezin cookbook survived. "It was a memoir in recipes of fantasy, longing, wishing; recipes remembered from a time before the war when women these women had husbands and children to feed and celebrations to prepare. ..." (De Silva 2005, p. 108). Mrs. Pachter's daughter, Anna Stern, made sure that the book would be available to the world. In Memory's Kitchen, a translation of the Terezin cook- 
book, gives the reader a chance to understand the history of the recipes as well as the daily routine of the imprisoned women. The cookbook did preserve treasured memories while giving the women a mental outlet for self-preservation during the horrific times (De Silva 1993, p. xxvi). For some, selling a cookbook that was created during this time seems incomprehensible, even disgraceful and outrageous. However, one must realize that it was in fact this cookbook and "cooking with their mouths" that made them free. Upon reflection, had this cookbook not survived, then the Nazi regime would have completed its mission: the extermination of the Jewish people.

The Soviet era was another period in history during which recipes in cookbooks hid secrets in a most ingenious and revealing way. Foods such as challah and stuffed cabbage were renamed, and recipes were recognizable to only Jews without the obvious label of a Jewish recipes or cookbook. A 1973 Soviet cookbook contained a recipe for sweet and sour stuffed cabbage. Jews would recognize this recipe as Jewish because this particular type of stuffed cabbage did not exist in Russian cooking. Instead it was termed "Stuffed Cabbage, Oriental Style" (Nakhimovsky 2006, p. 67). Once again, one can see that even in times of turmoil, Jewish recipes still somehow prevailed. Just as the existence of Judaism had to be hidden during the Soviet history, so too did the aspects of Jewish life, and in this case, cookbooks. At this point in history, the government cookbooks that replaced Ashkenazic Jewish cookbooks were centered around "good nutrition"-which is not to say that Jewish cookbooks did not contain recipes considered nutritious (Nakhimovsky 2006, pp. 69-70). History has proven that texts, even as trivial as cookbooks may seem to some, remain alive. For Jews, there is something in words, or in this case, recipes, that carries history, religion, and culture to future generations.

Cookbooks have become "kitchen windows." "The cookbook, like the diary and journal, evokes a universe inhabited by women both in harmony and in tension with their families, their communities, and the larger social world" (Theophano 2002, p. 6). Interestingly enough, by peering into a cookbook someone would be better to understand the times during which the author lived. Rochester's Hadassah Cookbook (1963) contains 335 pages of recipes and advertisements for such products as Coca-Cola and olives. This marketing tool encouraged Jewish families to purchase such products to enhance their meals and further assimilate into mainstream American culture.

It is universal to say that people, in general, have eating habits that replicate their families' eating habits. Although kashrut laws are often stretched, even ignored, outside the home, Jewish families typically still uphold tradition by keeping a kosher home to some extent. These cultural traditions have helped modern day Jews to follow their ancestors' cooking rules and cookbooks. If for no other reason, these traditions bring delight and comfort to the ones who show respect to ancestors.

Recent years have witnessed an explosion of interest in cooking-television shows, entire networks devoted to cooking, celebrity chefs and their cookbooks as well as their products, from food to roasting pans. After discussing the 
roles that cookbooks and their role in preserving Jewish culture and religion, one should consider the roles libraries play in this matter. With the advent of the library as an information powerhouse, making cookbooks available is necessary. This is especially true for public libraries. Nowadays, anyone can go into a library and check out popular and famous cookbooks. By providing access to a variety of Jewish cookbooks, libraries enable Jews from all over the world to discover new dishes that make their holidays and everyday meals more adventurous and tantalizing. One might wonder if these cookbooks are in fact valuable: but if they are considered trivial, then why would academic libraries carry these materials? An examination of the status of Jewish cookbooks and books about Jewish cooking in libraries might be revealing. If these resources are valued enough to be purchased and made available in libraries, then recipes are not the only significant features between the covers.

In order to demonstrate the value and importance placed on books featuring Jewish foods and cooking, an examination was conducted in OCLC WorldCat. Using the subject headings "Jewish Cookery" and "Cookery, Jewish," titles that had the most numerous holdings were identified. Table 1 contains the twenty most widely held titles according to WorldCat, along with author or editor, type of audience, and nonfiction/fiction designation. The ranking was determined by a combined total of original publication date and subsequent editions, versions, and formats such as electronic books.

\section{TABLE 1. THE TWENTY BOOKS WITH THE MOST HOLDINGS} IN LIBRARIES ACCORDING TO OCLC WORLDCAT

\begin{tabular}{|c|c|c|c|}
\hline Title & Author/Editor & Audience & \\
\hline 1. Cooking the Israeli Way & Josephine Bacon & Juvenile & Nonfiction \\
\hline $\begin{array}{l}\text { 2. The Book of Jewish Food: An Odyssey from } \\
\text { Samarkand to New York }\end{array}$ & Claudia Roden & Adult & Nonfiction \\
\hline 3. Jewish Cooking in America & Joan Nathan & Adult & Nonfiction \\
\hline 4. Grandma's Latkes & Malka Drucker & Juvenile & Fiction \\
\hline 5. Jalapeño Bagels & Natasha Wing & Juvenile & Fiction \\
\hline $\begin{array}{l}\text { 6. In Memory's Kitchen: A Legacy from the Women } \\
\text { of Terezin }\end{array}$ & Cara DeSilva & Adult & Nonfiction \\
\hline 7. Jewish Holidays All Year Round: A Family Treasury & llene Cooper & Juvenile & Nonfiction \\
\hline 8. Up from Orchard Street & Eleanor Widmer & Adult & Fiction \\
\hline 9. Miriam's Kitchen: A Memoir & Elizabeth Ehrlich & Adult & Nonfiction \\
\hline 10. Mrs. Greenberg's Messy Hanukkah & Linda Glaser & Juvenile & Fiction \\
\hline $\begin{array}{l}\text { 11. The Jewish Cultural Tapestry: International } \\
\text { Jewish Folk Traditions }\end{array}$ & Steven M. Lowenstein & Adult & Nonfiction \\
\hline $\begin{array}{l}\text { 12. Heirloom Cookbook: Recipes Handed Down by } \\
\text { Jewish Mothers and Modern Recipes from } \\
\text { Daughters and Friends }\end{array}$ & Miriam Lerner Satz & Adult & Nonfiction \\
\hline
\end{tabular}


TABLE 1. THE TWENTY BOOKS WITH THE MOST HOLDINGS IN LIBRARIES ACCORDING TO OCLC WORLDCAT

(continued)

\begin{tabular}{|c|c|c|c|}
\hline Title & Author/Editor & Audience & \\
\hline 13. The Jewish Holiday Book & Wendy Lazar & Juvenile & Nonfiction \\
\hline 14. Beni's Family Cookbook for the Jewish Holidays & Jane Breskin Zalben & Juvenile & Nonfiction \\
\hline 15. Jewish Holiday Cookbook & Susan Gold Purdy & Juvenile & Nonfiction \\
\hline 16. Jewish Holiday Fun & Judith Hoffman Corwin & Juvenile & Nonfiction \\
\hline $\begin{array}{l}\text { 17. The Children's Jewish Holiday Kitchen: } 70 \text { Ways to } \\
\text { Have Fun with Your Kids and Make Your Family's } \\
\text { Celebrations Special }\end{array}$ & Joan Nathan & Juvenile & Nonfiction \\
\hline $\begin{array}{l}\text { 18. Fast \& Festive Meals for the Jewish Holidays: } \\
\text { Complete Menus, Rituals, and Party-Planning } \\
\text { Ideas for Every Holiday of the Year }\end{array}$ & Marlene Sorosky & Adult & Nonfiction \\
\hline 19. The Jewish Tradition: A Year of Foods and Festivities & Judith Fellner & Adult & Nonfiction \\
\hline $\begin{array}{l}\text { 20. The Jewish Holiday Cookbook: An International } \\
\text { Collection of Recipes and Customs }\end{array}$ & Gloria Kaufer Greene & Adult & Nonfiction \\
\hline
\end{tabular}

The twenty titles are equally divided with respect to the intended audience, juvenile and adult. In addition, sixteen titles are non-fiction and four are fiction. Of the four fiction titles, three are juvenile books and one is adult. Women are authors or editors of nineteen of these items, and only one has a male author. From a cursory examination of the titles, eleven books focus on Jewish holidays.

Once the top twenty titles were identified, the next step was to examine the holdings in relation to the library type. The libraries were classified as follows: public, school, academic and special. Public libraries include free, regional, district, and county facilities. School libraries, both public and private, refer to elementary, middle, high school, and school board facilities. Academic libraries are defined as university, college, seminary and theological, vocational, technical and community college. Special libraries include vendor, library networks, state, national, federal, government, business/corporate, associations or foundations, temple/synagogue, state municipal government, and unidentified.

Public libraries overwhelming contain the highest number of holdings. Academic libraries represent the next library type that has substantial holdings; however, it is necessary to note that in most of the titles, the gap between the holdings of the public and academic library is substantial. Public libraries have the most numerous holdings for seventeen of the titles, while academic libraries have the most holdings for the following three titles: In Memory's Kitchen, The Jewish Cultural Tapestry, and Heirloom Cookbook. Worth noting is that The Jewish Cultural Tapestry is the sole book with a male author. Holdings for $\mathrm{K}-12$ public and private school libraries, as well as special libraries, are represented under each title. (For detailed holdings statistics for each title, See Appendix.) 


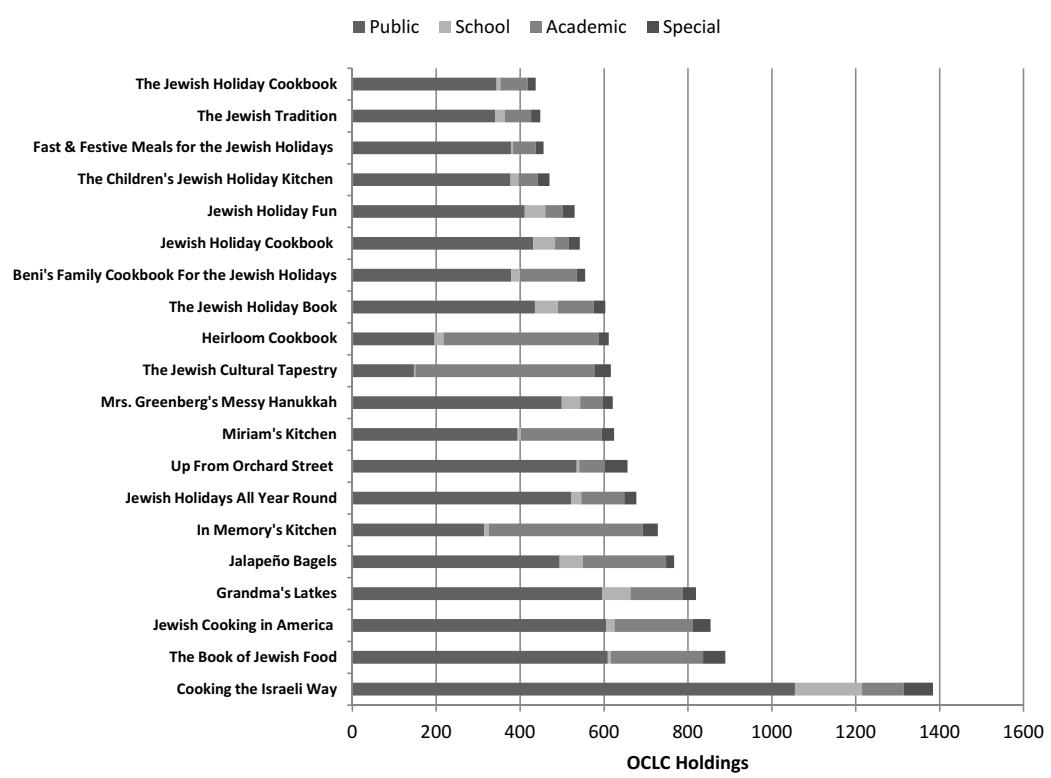

FIGURE 1. Top twenty titles and their library holdings according to library type.

Since most of the top twenty titles are cookbooks, the majority of these titles are nonfiction. Therefore, any supplemental text to the recipes included in these books contains factual and educational information that can be used to preserve Jewish traditions. As mentioned earlier in this article, women traditionally passed down cooking knowledge. This could explain why women represent almost all of the authors and editors of these titles.

Although juvenile and adult books are divided equally, the data for the individual titles (see Appendix) reveal that the juvenile books do in fact have very substantial numbers of library holdings. One of the reasons that juvenile books are purchased by libraries is that passing on traditions to young readers actually embeds culture at an early age. The three most popular juvenile titles are excellent examples of the importance of books about Jewish cooking. The first title, Cooking the Israeli Way, is a 1986 cookbook that provides information about life in Israel in addition to containing actual recipes. The second title, Grandma's Latkes, is an educational story for both young Jewish and non-Jewish readers. Molly's grandmother explains the background as well as the significance of food and customs for Hanukkah. The third title, Jalapeño Bagels, presents a thoughtful story of Pablo and his blended family. His Jewish father and his Mexican-American mother have successfully preserved and passed down traditions from both ethnicities.

Academic libraries do have significant holdings of Jewish cookbooks and books about Jewish cooking. The three titles whose holdings are the most numerous in higher education libraries, In Memory's Kitchen, The Jewish Cultural Tapestry, and Heirloom Cookbook, are evidence that books about cooking contain valuable information that is worthy of study. The varied information-historical, socio-eco- 
nomic, biographical, and much more-provides students with insight that is often omitted from standard academic texts. Therefore, as more Jewish cookbooks and books about Jewish cooking find themselves on academic library shelves, their status as cultural vehicles heightens as well as serving their populations.

School and special libraries represent a very small number of libraries in respect to the top twenty books about Jewish cooking. Understandably their numbers are low because these libraries do not traditionally contribute to WorldCat. However, if school and special libraries were individually surveyed, one could speculate that they would most likely contain statistics similar to other libraries.

\section{CONCLUSION}

The Ten Commandments provided rules and guidelines that are still observed by Jewish families and communities during holidays and everyday life. The precepts as outlined in the Torah include specific guidance regarding food and diet-and as such it may arguably be considered the first Jewish cookbook. Until the emergence of the printing press and, most recently, the Internet, Jewish culinary traditions that have been passed from generation to generation have relied upon the oral tradition. Culinary arts and religious practices have become so intertwined that it is often difficult to differentiate the two. As women have passed on their recipes, whether orally or written, they have in fact been preserving their Judaic roots.

Whether one looks at historic cookbooks from previous centuries, the Holocaust, or today, the message is clear. Cookbooks and books about cooking preserve more than recipes; they carry a people, a religion, and a nation. The Jewish population must remember its roots, and some of those roots are based in Jewish cooking. As important as it is for Jewish libraries to consider the value of cookbooks in preserving Jewish culture, non-Jewish libraries, whether academic or public, $\mathrm{K}-12$ or special, can also share in this mission.

Judaism is rich both in writings and in customs. We have suggested that the Torah, Ten Commandments, and cookbooks are all related. Jewish families spend time together praying and sharing meals every Shabbat. That means that it is customary for the woman and children to prepare meals together and pass along these cooking traditions in order to celebrate life, the Bible, and family. It is these moments in everyday life, celebration, and religious observances that provide Jews with the means to preserve their religion, culture, and tradition.

\section{SOURCES}

Abusch-Magder, Ruth (1997). "Cookbooks," Jewish Women in America: An Historical Encyclopedia. New York: Routledge, (1997), pp. 281-287.

Amster, Linda, ed. (2003). The New York Times Jewish Cookbook. New York: St. Martin's Press, 2003. 
Avakian, Arlene Voski (1997). Through the Kitchen Window: Women Writers Explore the Intimate Meanings of Food and Cooking. Boston: Beacon Press, 1997.

Bardenstein, Carol (2002). “The Gender of Nostalgia," Signs: Journal of Women in Culture and Society 28:1 (2002): 353-387.

Biemiller, Lawrence (2002). “Eat First: Then You'll Learn,” The Faculty Page, The Chronicle of Higher Education (May 17, 2002): A56.

Bone, Marci Zabell; Rubenstein, Joanne, eds. (2000). Tastes of Judaism: Recipes, Rituals, and Reflections. Beachwood, OH: Fairmount Temple, 2000.

Brauch, Julia; Lipphardt, Anna; Nocke, Alexandra, eds. (2008). Jewish Topographies: Visions of Space, Traditions of Place. Burlington, VT: Ashgate Publishing Company, 2008.

Buhle, Paul, ed. (2007). Jews and American Popular Culture. Westport, CT: Praeger Publishers, 2007.

Cohen, Jayne (2000). The Gefilte Variations: 200 Inspired Re-creations of Classics from the Jewish Kitchen, with Menus, Stories, and Traditions for the Holidays and Year-round. New York: Scribner, 2000.

Cooper, John (1993). Eat and Be Satisfied: A Social History of Jewish Food. Northvale, NJ: Jason Aronson, 1993.

Davidson, Alan (2006). The Oxford Companion to Food. New York: Oxford University Press, 2006.

De Silva, Cara (1993). In Memory's Kitchen: A Legacy from the Women of Terezin. Northvale: NJ: Jason Aronson, Inc., 1993.

De Silva, Cara (2005). “In Memory's Kitchen: Reflections of a Recently Discovered Form of Holocaust Literature," Food \& Judaism, Greenspoon, Leonard J.; Simkins, Ronald A.; Shapiro, Gerald, eds. (Omaha, NE: Creighton University Press, 2005): 105-117.

Drews, Marie I. (2008). "Cooking in Memory's Kitchen: Re-Presenting Recipes, Remembering the Holocaust," Edible Ideologies: Representing Food \& Meaning, Kathleen LeBesco; Peter Naccarato, eds. (Albany, NY: State University of New York, 2008).

Eves, Rosalyn Collings (2005). "A Recipe for Remembrance: Memory and Identity in African American Women's Cookbooks," Rhetoric Review 24:3 (2005): 280-297.

Fellner, Judith B. (1995). In the Jewish Tradition: A Year of Food and Festivities. New York, NY: Michael Friedman Publishing Group Inc., 1995.

Ferris, Marcie Cohen (1999). "'From the Recipe File of Luba Cohen': A Study of Southern Jewish Foodways and Cultural Identity," Southern Jewish History 2 (1999): 129-164.

Glazer, Phyllis; Glazer, Miriyam (2004). The Essential Book of Jewish Festival Cooking. New York, NY: HarperCollins, 2004.

Green, Gloria Kaufer (1985). The Jewish Holiday Cookbook: An International Collection of Recipes and Customs. New York: Times Books, 1985.

Greenspoon, Leonard J.; Simkins, Ronald A.; Shapiro, Gerald, eds. (2005). Food \& Judaism. Omaha, NE: Creighton University Press, 2005.

Hadassah, The Women's Zionist Organization of America (1963). Rochester's Hadassah Cookbook. Rochester, NY: Rochester Chapter of Hadassah, 1963.

Handerson, Heike (2006). "Cooking up Memories: The Role of Food Recipes, and Relationships in Jeannette Lander's Überbleibsel," Women in German Yearbook: Feminist Studies in German Literature \& Culture 22 (2006): 236-258.

Jochnowitz, Eve (2005). "Smoked Salmon Sushi and Sturgeon Stomachs: The Russian Jewish Foodscapes of New York," Food \& Judaism, Greenspoon, Leonard J.; Simkins, Ronald A.; Shapiro, Gerald, eds. (Omaha, NE: Creighton University Press, 2005): $15-25$.

Katz, Jonathan; Katz, Solomon H.; Weaver, William Woys, eds. (2003). Encyclopedia of Food and Culture. New York: Scribner, 2003. 
King, Roger J. H. (2007). "Eating Well: Thinking Ethically about Food," Food \& Philosophy: Eat, Drink and Be Merry, Allhoff, Fritz and Monroe, Dave, eds. (Malden, MA: Blackwell, 2007): 177-191.

Kirshenblatt-Gimblett, Barbara (1987a). "The Kosher Gourmet in the Nineteenth Century Kitchen," The Journal of Gastronomy 2:4 (1986-1987): 51-89.

Kirshenblatt-Gimblett, Barbara (1987b). "Recipes for Creating Community: The Jewish Charity Cookbook in America," Jewish Folklore and Ethnology Review 9:1 (1987): 8-11.

Kirshenblatt-Gimblett, Barbara (1990). "Kitchen Judaism," Getting Comfortable in New York: The American Jewish Home, 1880-1950, Braunstein, Susan L.; Joselit, Jenna Weissman, eds. (New York: The Jewish Museum, 1990): 77-105.

Kramer, David Charles (2007). Jewish Eating through the Ages. New York: Routledge, 2007.

Luard, Elisabeth (2001). Sacred Food: Cooking for Spiritual Nourishment. Chicago: M.Q. Publications Limited, 2001.

Mintz, Sidney W. (1996). Tasting Food, Tasting Freedom: Excursions into Eating, Culture, and the Past. Boston: Beacon Press, 1996.

Montefiore, Judith C.; Raphael, Chaim (1983). The Jewish Manual, or, Practical Information in Jewish \& Modern Cookery with a Collection of Valuable Recipes \& Hints Relating to the Toilette. New York: NightinGale Books, 1983.

Nakhimovsky, Alice (2006). "You Are What They Ate: Russian Jews Reclaim Their Foodways," Shofar: An Interdisciplinary Journal of Jewish Studies 25:1 (2006): 63-77.

Nathan, Joan (1998). Jewish Cooking in America. New York: Alfred A. Knopf, 1998.

Nathan, Joan (2004). Joan Nathan's Holiday Cookbook. New York: Schocken Books, 2004.

Nathan, Joan (2004). "Family Treasures Hold Kosher America's Roots," The New York Times (March 31, 2004): F1.

Plotch, Batia; Cobe, Patricia, eds. (1992). The Kosher Gourmet: By the 92nd Street Y Cooking School. New York: Ballantine Books, 1992.

Pollak, Oliver B. (2005). "Nebraska Jewish Charitable Cookbooks 1901-2002," Food \& Judaism, Greenspoon, Leonard J.; Simkins, Ronald A.; Shapiro, Gerald, eds. (Omaha, NE: Creighton University Press, 2005): 133-148.

Rose, Evelyn (2004). The New Complete International Jewish Cookbook. London: The Chrysalis Books Group, 2004.

Roth, Norman, ed. (2003). Medieval Jewish Civilization: An Encyclopedia. New York: Routledge, 2003.

Schur, Sylvia (1963). “Jewish Cooking," Saturday Evening Post 236:6 (1963): 64-66.

Schwartz, Arthur (2008). Arthur Schwartz's Jewish Home Cooking: Yiddish Recipes Revisited. Berkeley, CA: Ten Speed Press, 2008.

Serbe, Diane, ed. (2008). In Mama's Kitchen (website): http://www.inmamaskitchen.com (accessed May 1, 2011).

Shaftesley, John M. (1975). "Culinary Aspects of Anglo-Jewry." Folklore Research Center Studies 5 (1975): 367-400.

Skolnik, Fred, ed. (2007). Encyclopaedia Judaica. 2nd ed. Detroit: Macmillan Reference USA in association with the Keter Publishing House, 2007.

Smith, Andrew F, ed. (2007). The Oxford Companion to American Food and Drink. Oxford; New York: Oxford University Press, 2007.

Theophano, Janet (2002). Eat My Words: Reading Women's Lives through the Cookbooks They Wrote. New York: Palgrave, 2002.

Tucker, Charlotte E. (2004) "Chicken Soup: Long Simmered in Tradition," USA Today (March 29, 2004): 7D.

Weiss, Elliott (2004). "Packaging Jewishness: Novelty and Tradition in Kosher Food Packaging," Design Issues 20:1 (2004): 48-61. 


\section{APPENDIX}

CHART 1. Cooking the Israeli Way

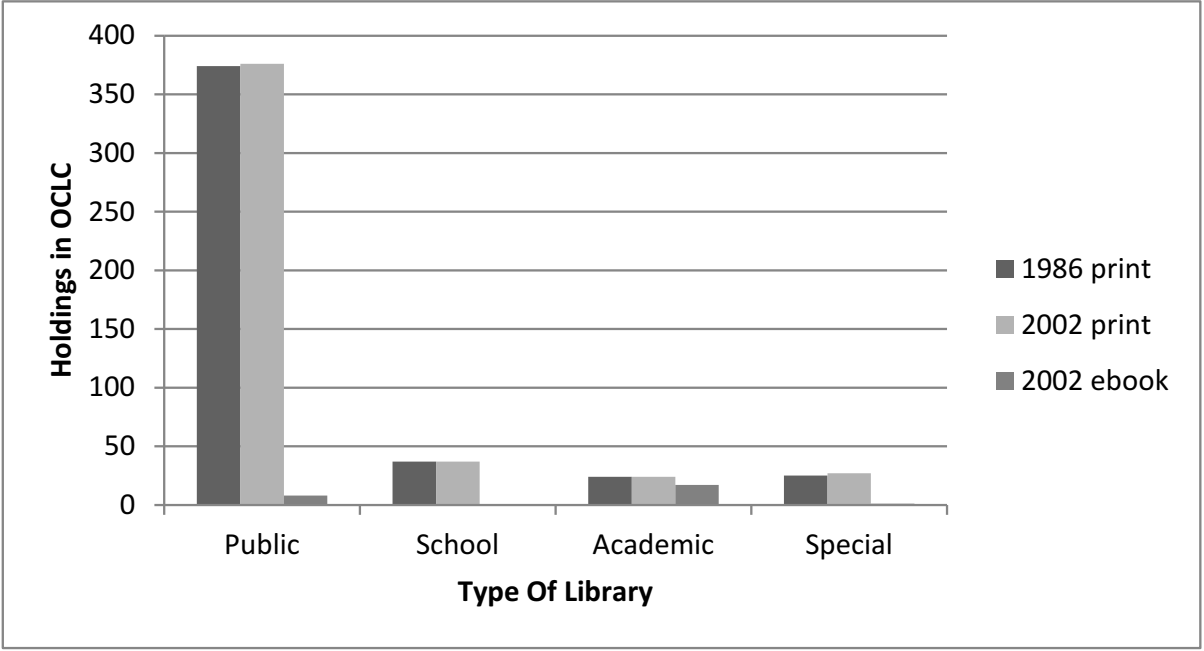

CHART 2. The Book of Jewish Food

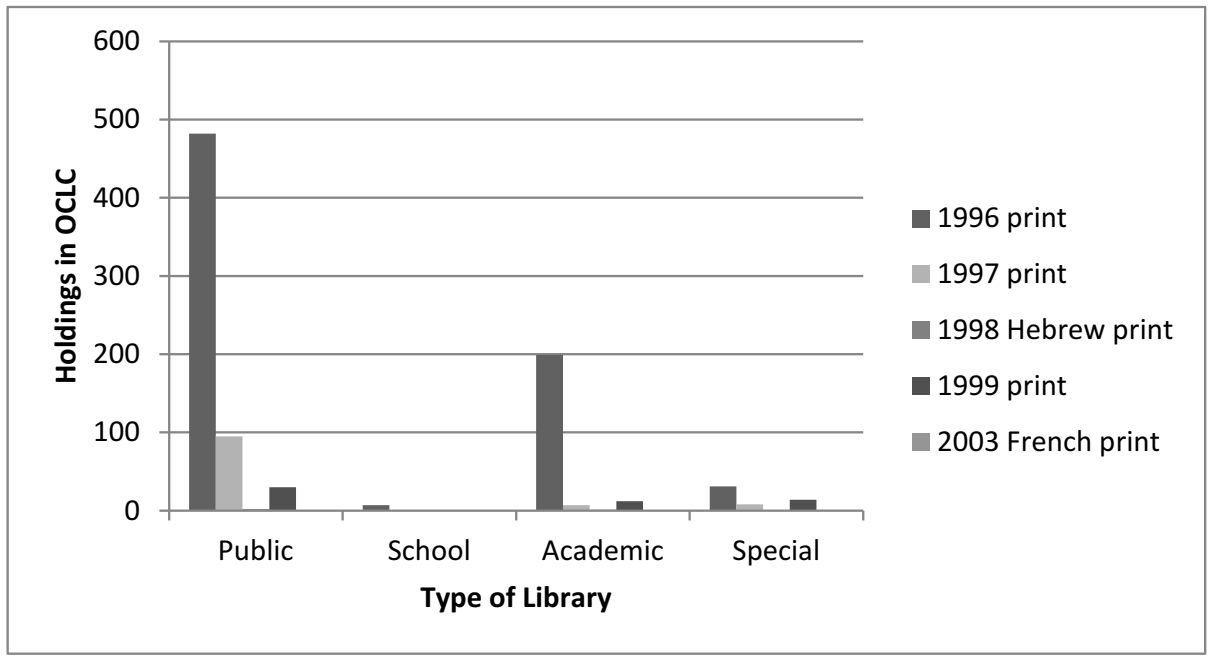




\section{CHART 3. Jewish Cooking in America}

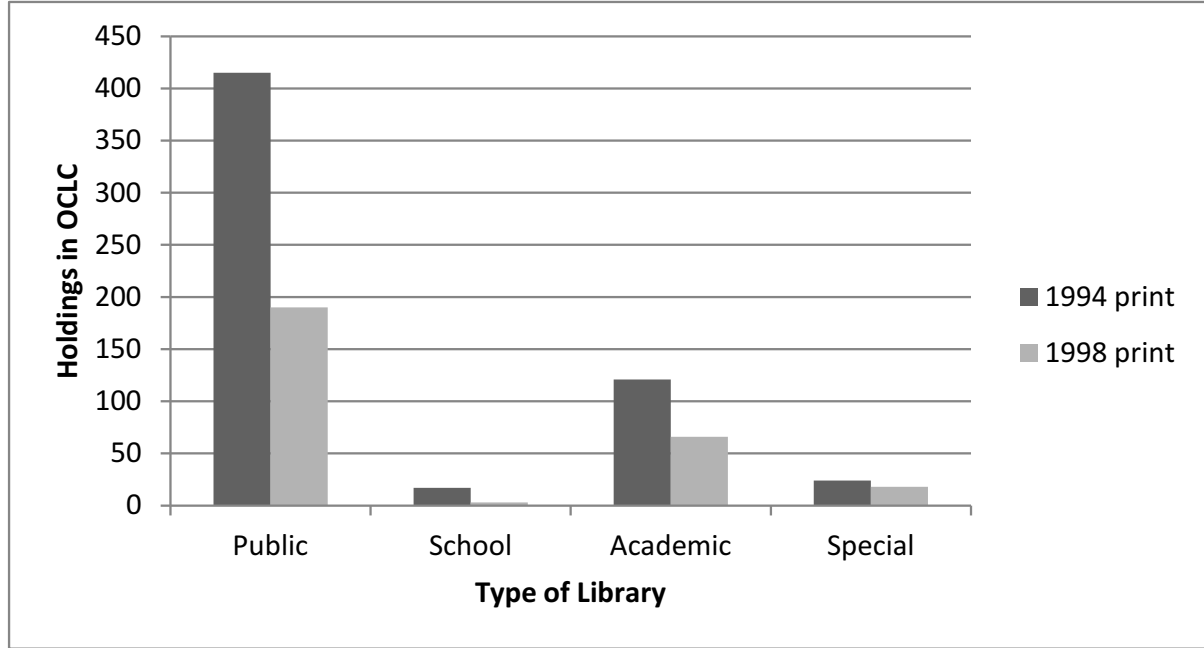

CHART 4. Grandma's Latkes

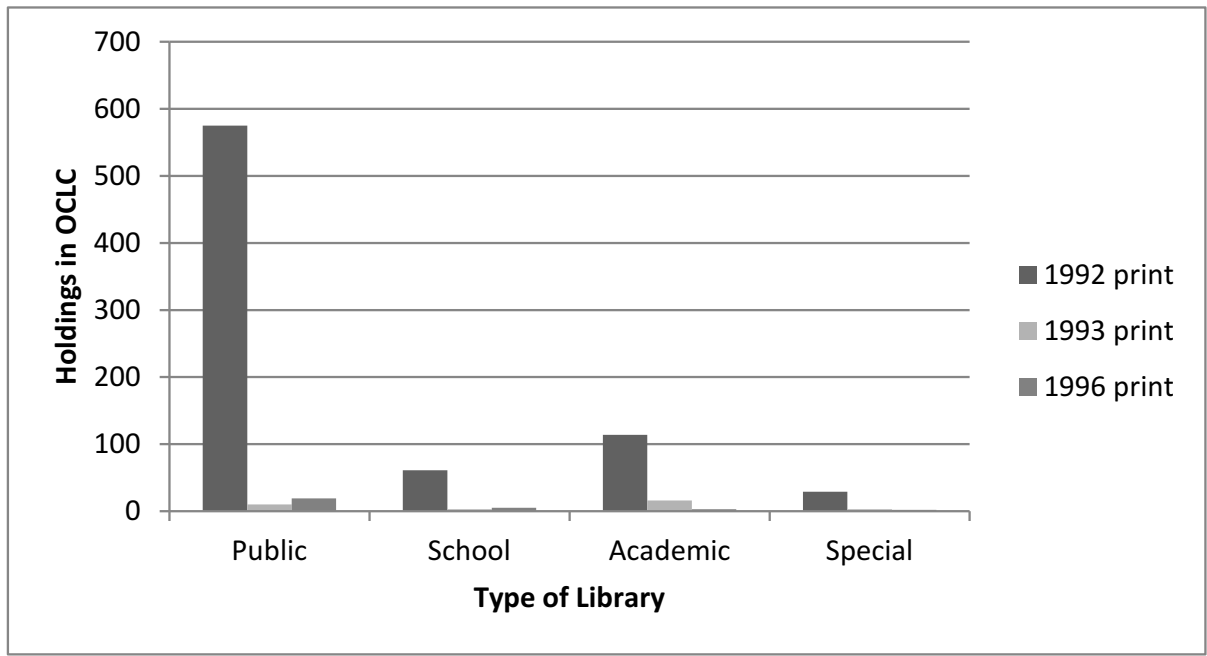


CHART 5. Jalapeño Bagels

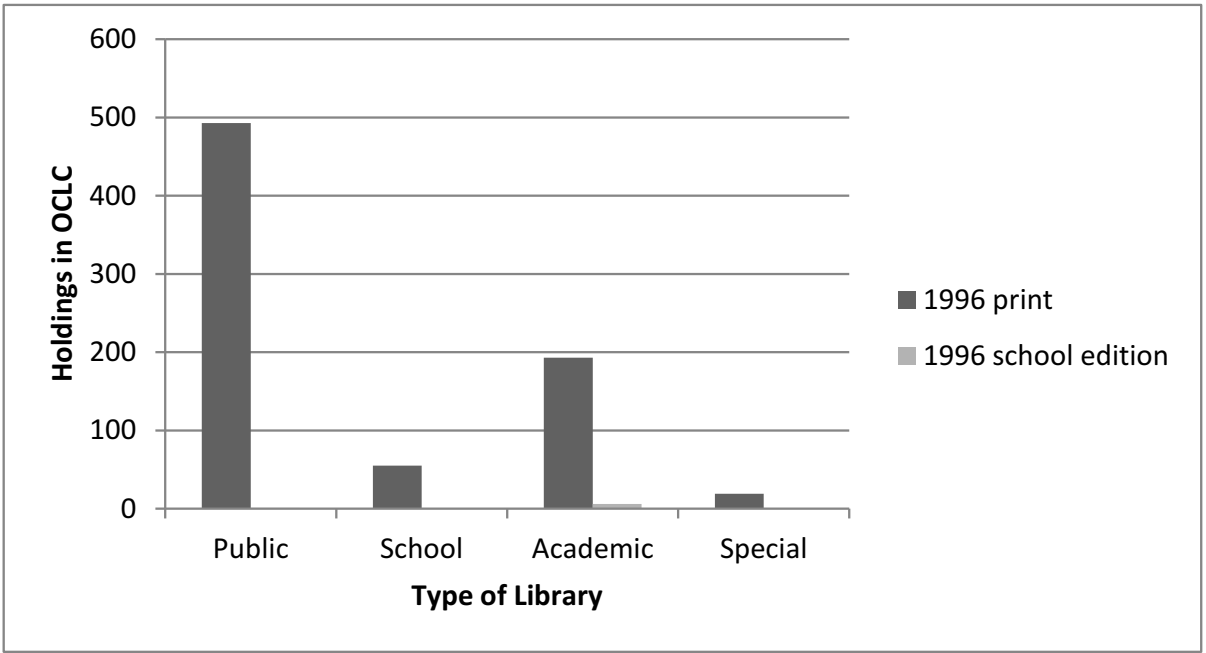

CHART 6. In Memory's Kitchen

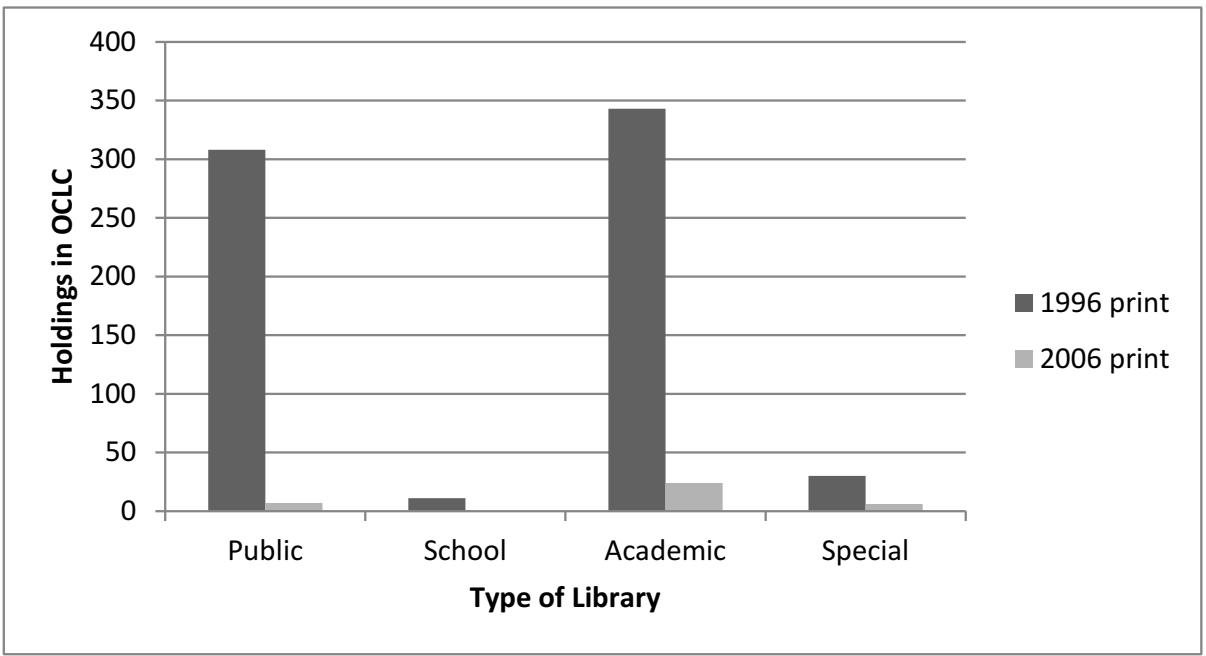




\section{CHART 7. Jewish Holidays All Year Round}

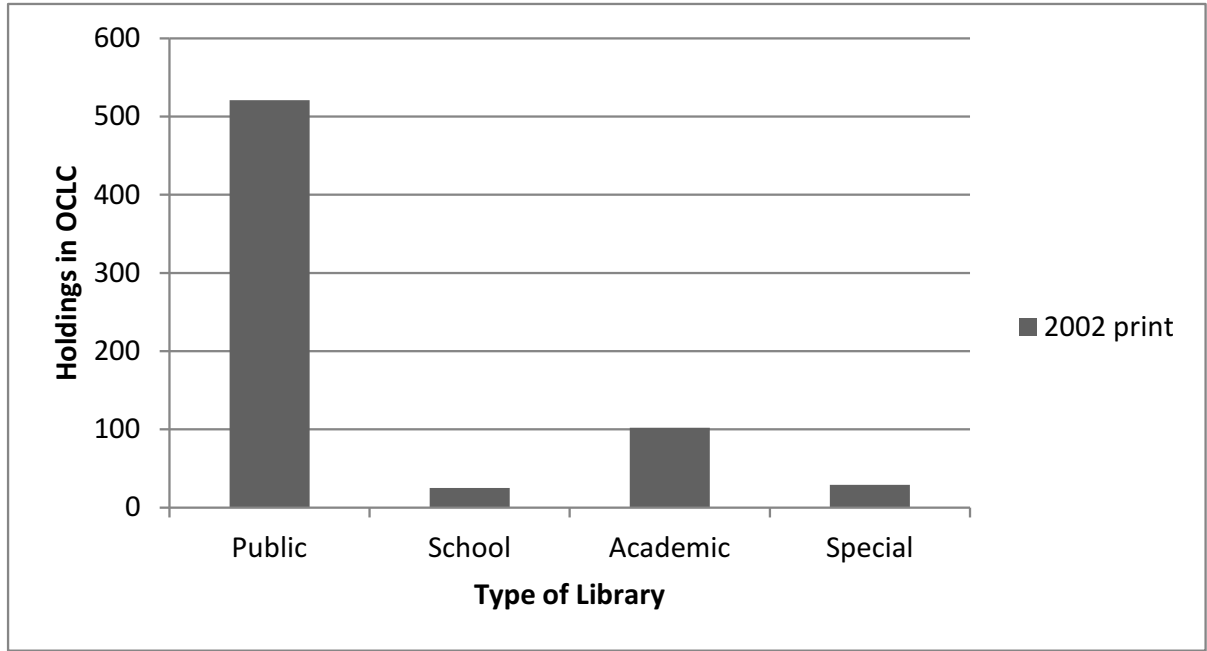

\section{CHART 8. Up from Orchard Street}

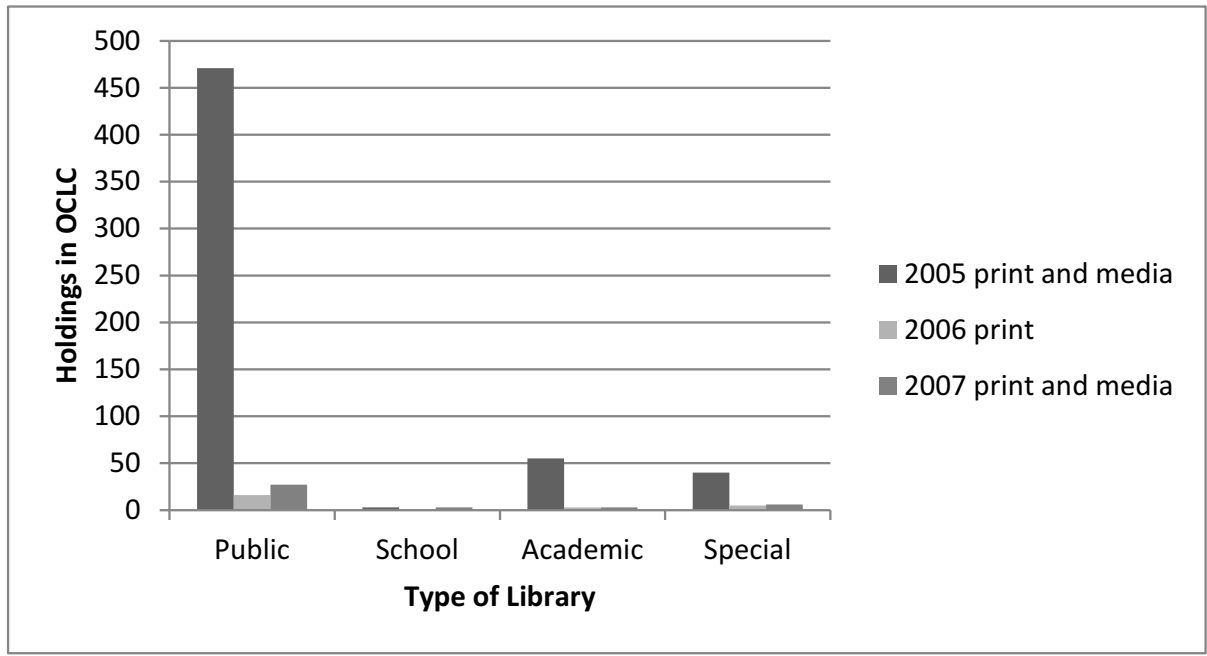




\section{CHART 9. Miriam's Kitchen}

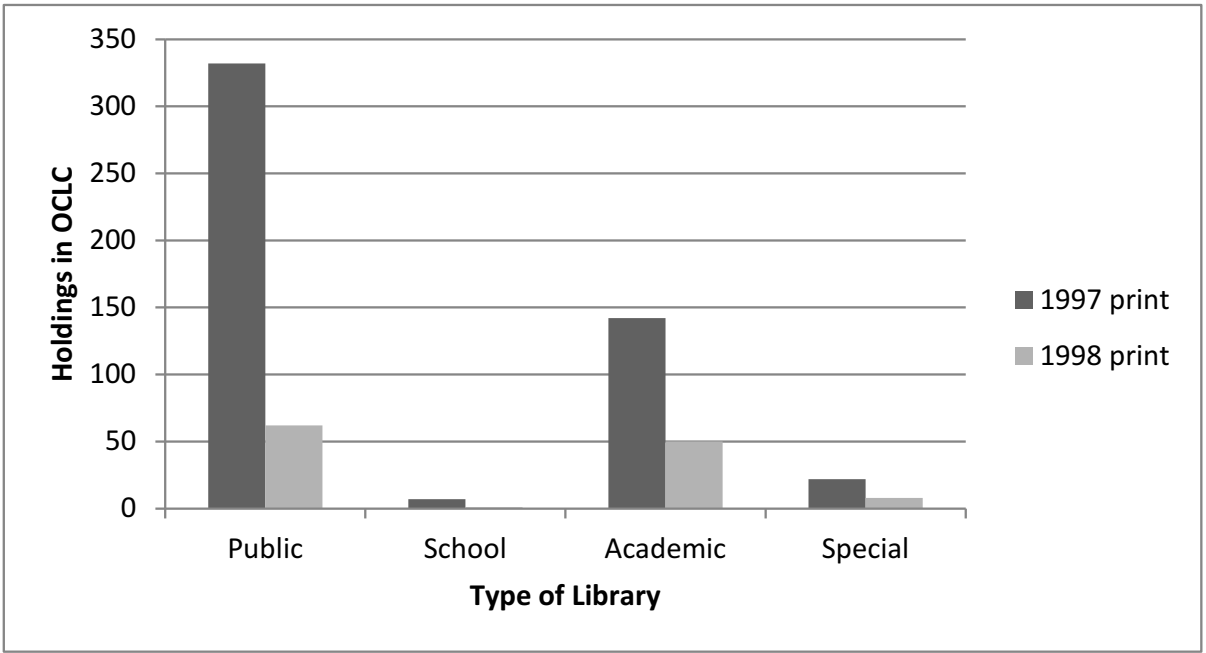

CHART 10. Mrs. Greenburg's Messy Hanukkah

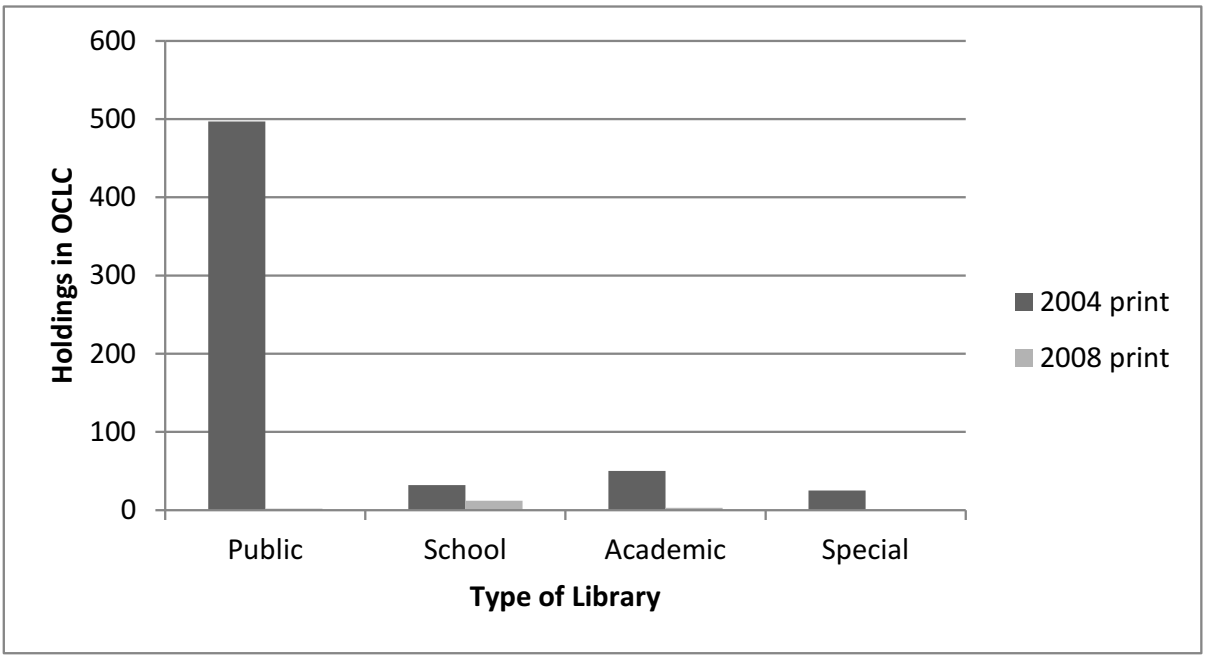




\section{CHART 11. The Jewish Cultural Tapestry}

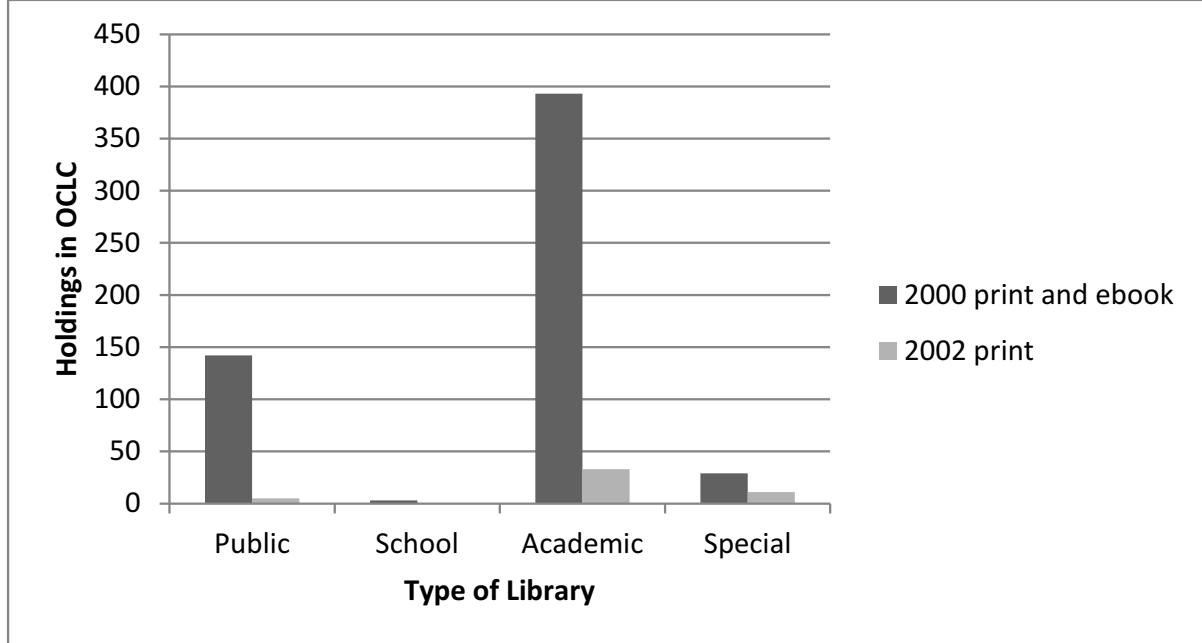

CHART 12. Heirloom Cookbook

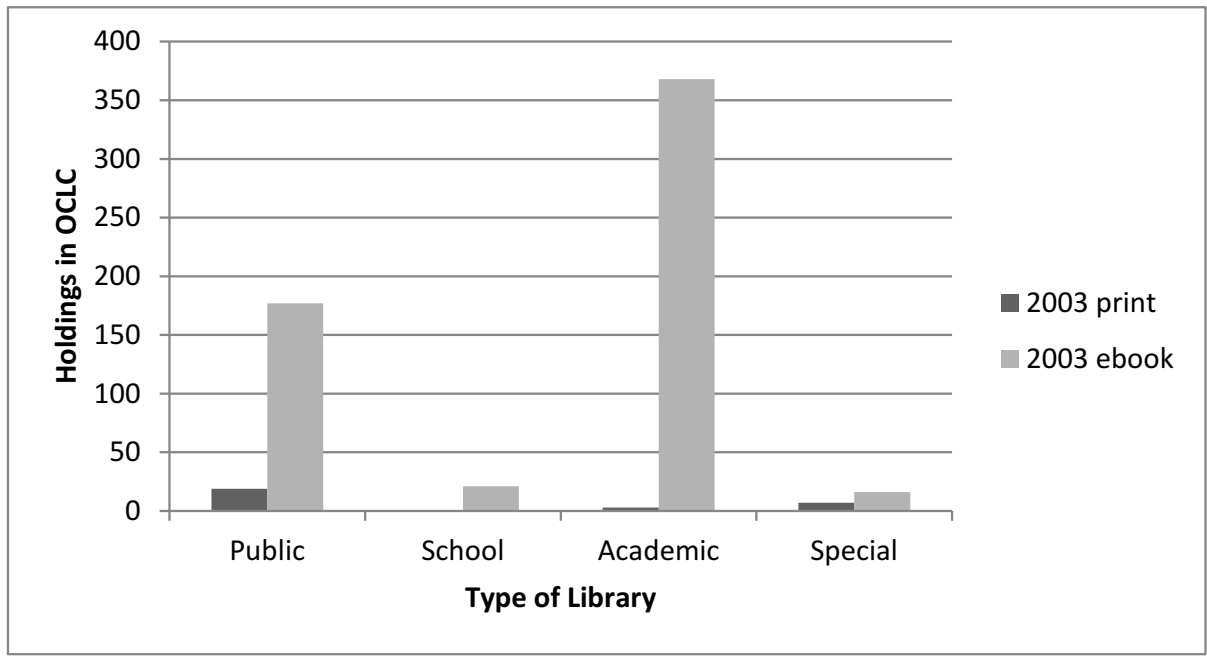


CHART 13. The Jewish Holiday Book

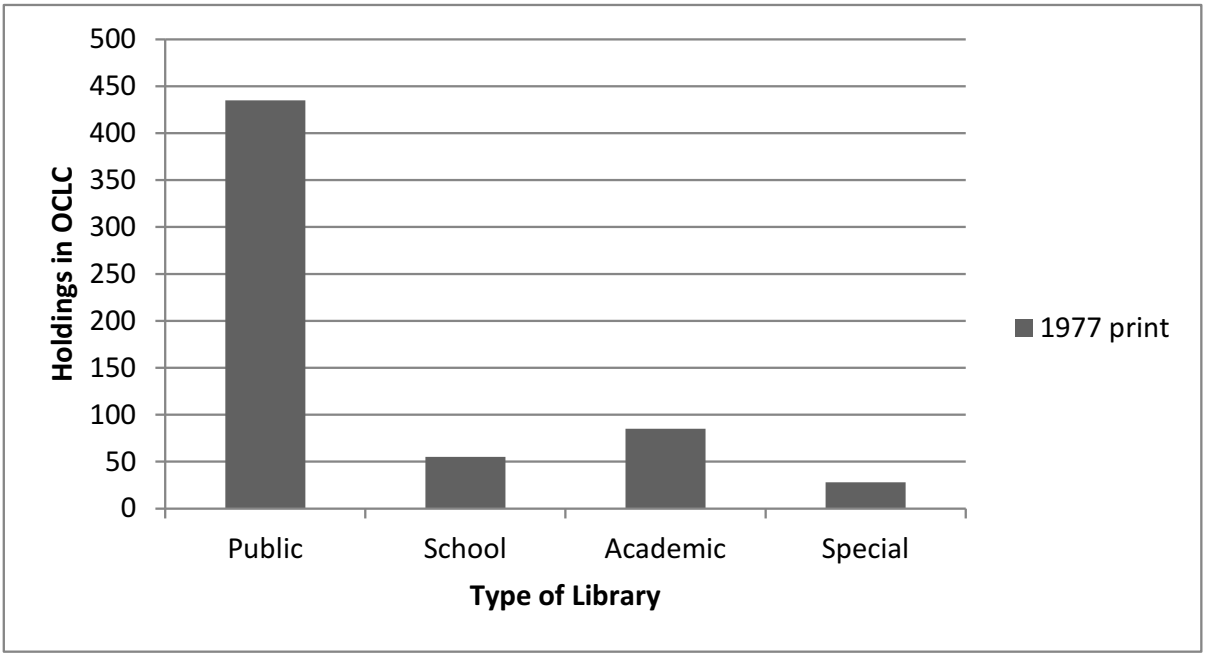

CHART 14. Beni's Family Cookbook for the Jewish Holidays

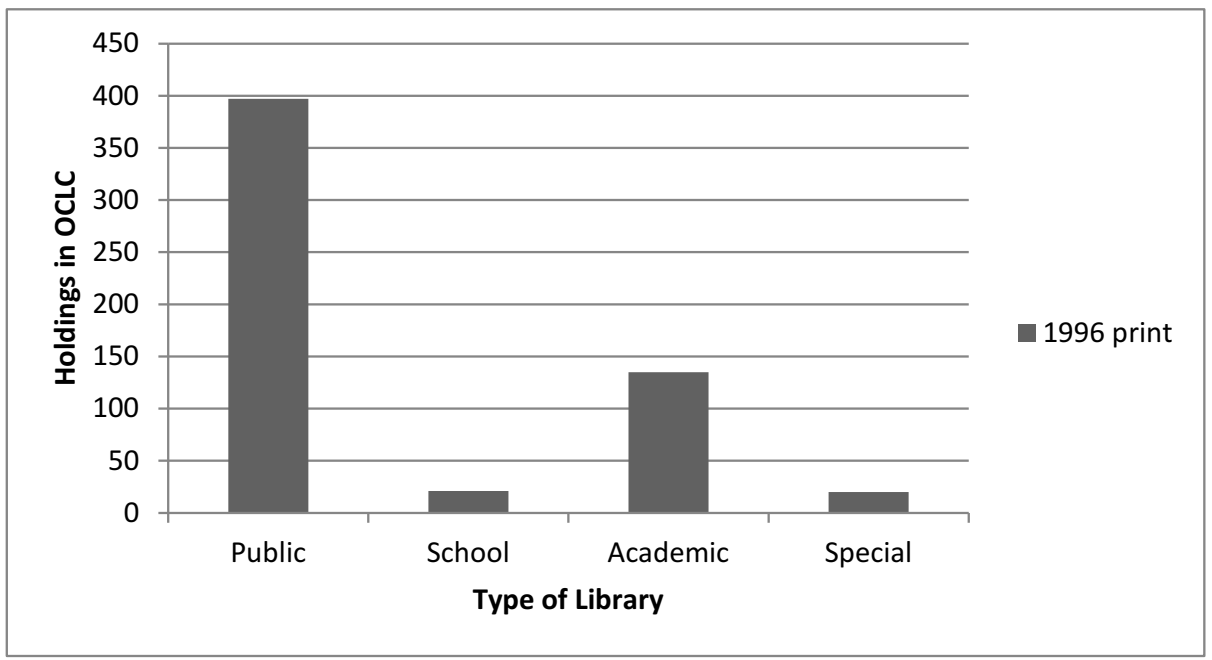


CHART 17. The Children's Jewish Holiday Kitchen

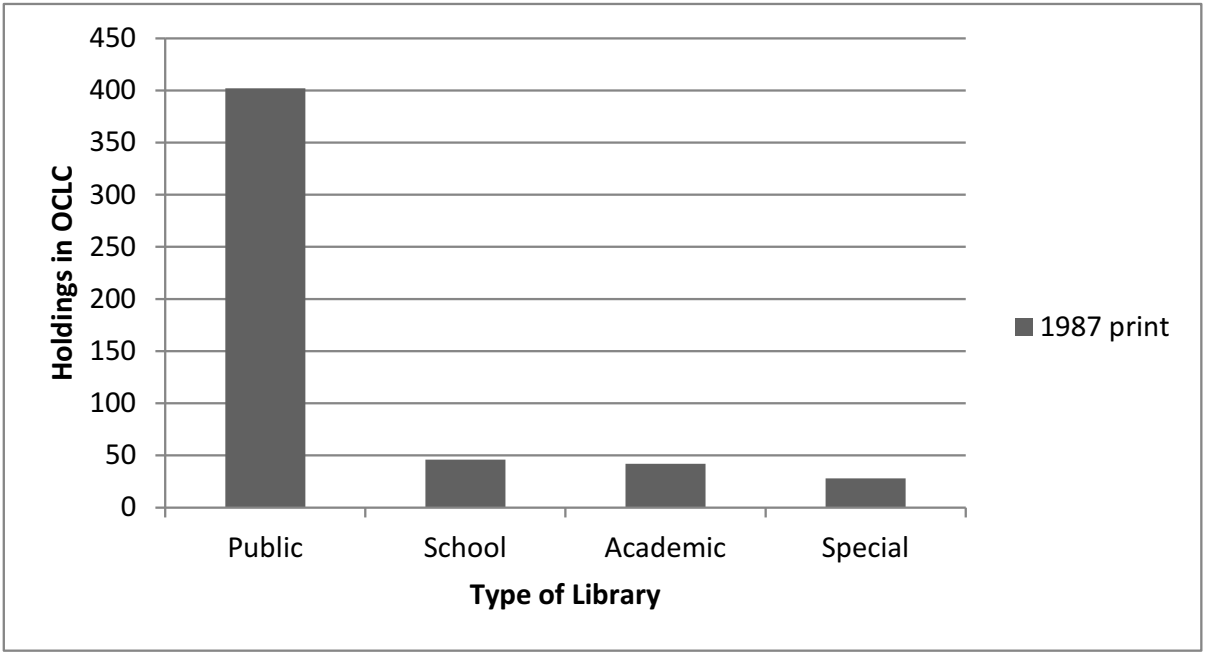

CHART 18. Fast and Festive Meals for the Jewish Holidays

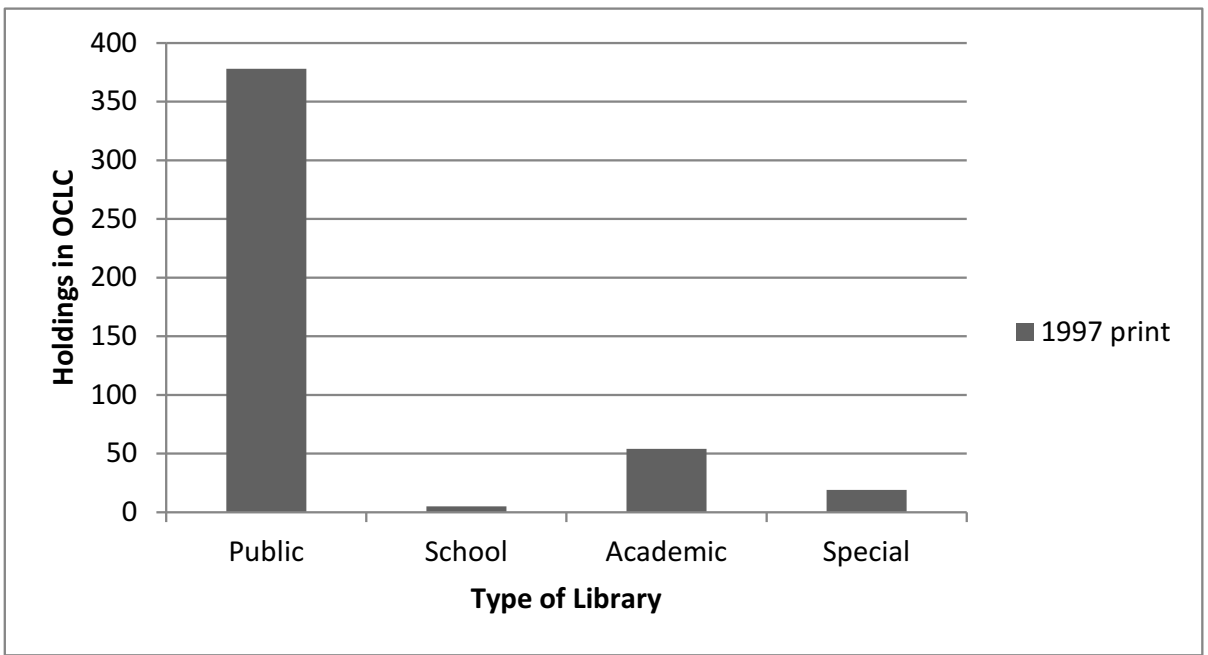




\section{CHART 19. The Jewish Tradition: A Year of Foods and Festivities}

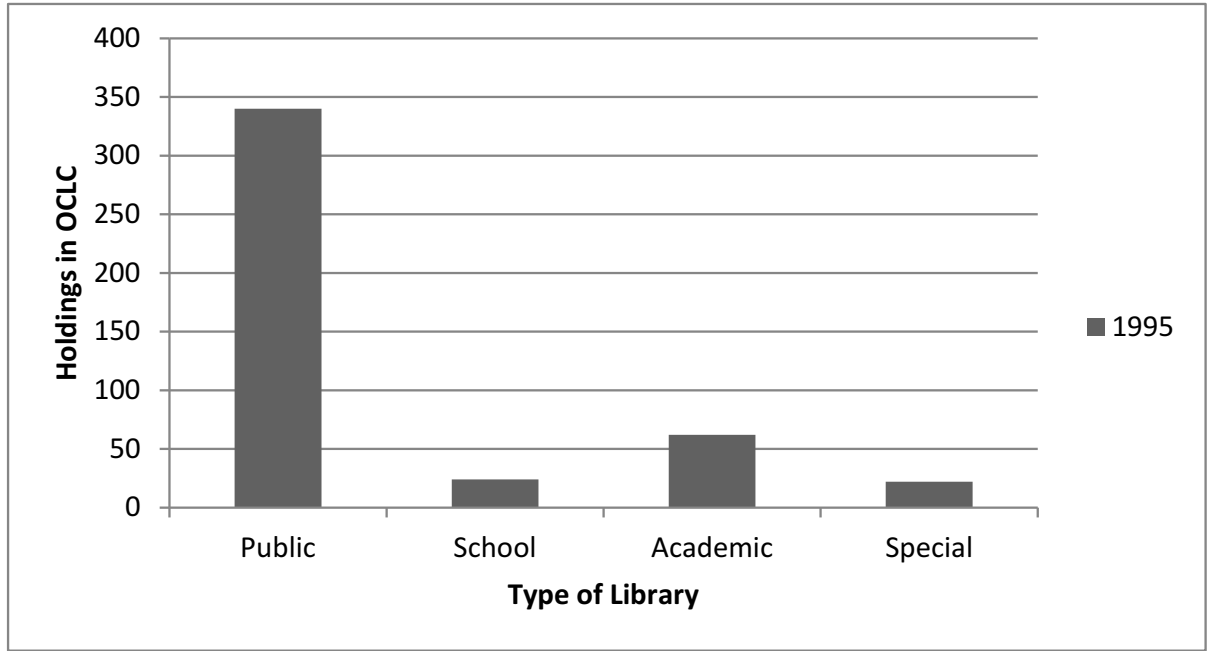

\section{CHART 20. The Jewish Holiday Cookbook}

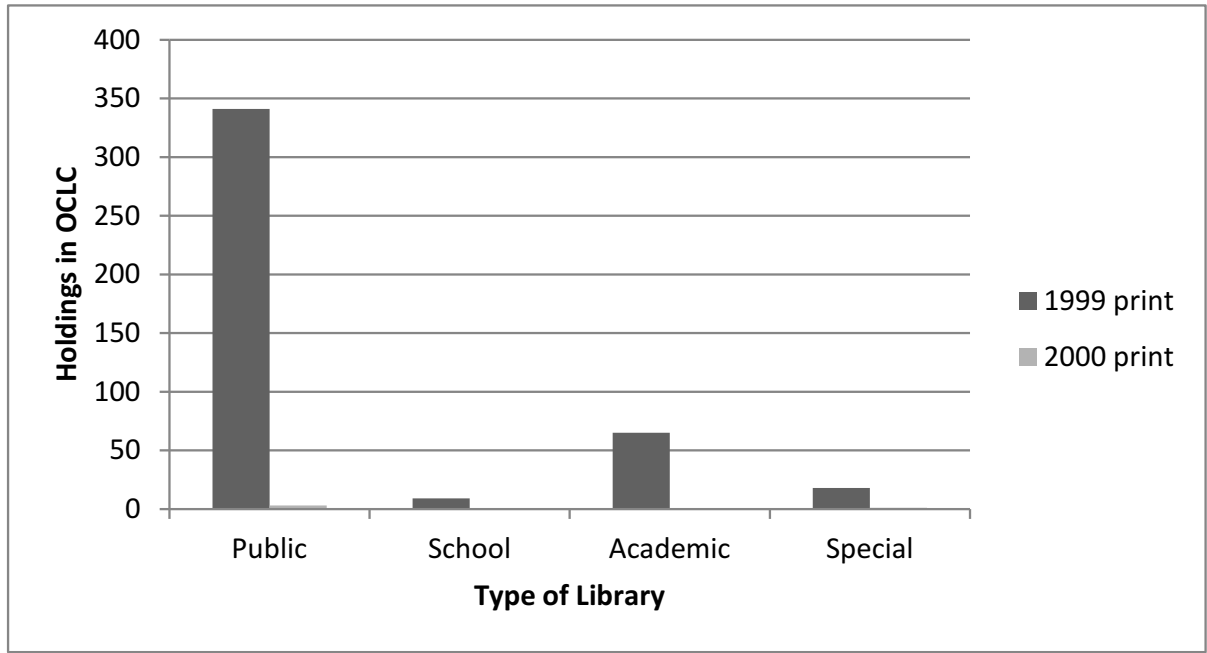

\section{$\diamond \diamond \diamond$}

As an Associate Lecturer of Information Literacy for the University Libraries at the University of Toledo, Professor Daniel E. Feinberg provides information literacy instructional sessions for students and faculty. In addition to teaching and providing reference assistance, he has presented at the state and national level and has published in the areas of information literacy and collection development.

Professor Alice Crosetto's career spans over thirty years as an educator and librarian at both the high school and university level. As the current Coordinator for Collection Development for the University of Toledo Libraries, she oversees monographs and media purchases, and has presented and published on a variety of topics including collection evaluation, disabilities and disorders, and children's literary awards. 